\title{
O Direito Internacional no alvorecer do século XXI
}

\section{MANFRED LACHS}

$\grave{A}$ $s$ vezes, quando olhamos o calendário, constatamos que o tempo passa com demasiada lentidáo; mais freqüentemente, porém, achamos que o tempo passou muito depressa e sem que percebêssemos. Quero lembrar-lhes que nos aproximamos do fim do século XX.

Hoje, é sob o signo do tempo - do tempo que passa - que se apóia minha exposiçáo. Em que ponto está o Direito Internacional às vésperas do século XXI?

Ainda que eu seja objeto de críticas por exprimir coisas conhecidas, até banais, faço questão, entretanto, de dizer, logo de início, que, se quisermos entreabrir a porta do século $\mathrm{XXI}$, é preciso antes avaliar, fazer o balanço do século que termina.

Este procedimento tem dupla finalidade. Alguns historiadores afirmaram que o "saber deve ser utilizado para fins de ordem filosófica. O conhecimento deve guiar a marcha da humanidade" . Outros estimaram que enquanto não tivermos feito, de forma ativa e enérgica, uma interpretaçáo autêntica da história dos homens em todas as suas dimensóes, teremos fracassado em cumprir de modo adequado nossos deveres profissionais. Não podemos nos atrever a deixar o mundo em que vivem nossos semelhantes permanecer incompreensível do ponto de vista histórico (1). É preciso voltar ao passado e evocar a abordagem da história de Rousseau que se apresenta sob a forma de uma ode à posteridade. Mas, ao mesmo tempo, é preciso mencionar as dúvidas de Voltaire: $\mathrm{O}$ apelo à história atinge verdadeiramente seu objetivo?

O período abrangido pelo século XIX e começo do século XX foi uma era na qual a tradiçáo clássica do Direito Internacional, como a invocamos hoje, havia atingido e mantido sua velocidade de cruzeiro, enquanto as idéias "daqueles que ocupavam os postos de comando tendiam a tornar-se uniformes.

O decênio do Direito Internacional proclamado pelas Naçóes Unidas é acontecimento dos mais úteis; permite importante troca de opiniōes quanto ao estado do direito e às necessidades de seu desenvolvimento ulterior. 
O que ficou de particularmente notável deste século que atravessamos? Seus primeiros avanços foram marcados pela permanência do caráter eurocêntrico do Direito Internacional. Foi apenas gradativamente que outros Estados conseguiram penetrar nesse clube fechado, representado pela sociedade dos Estados, cujas dimensóes coincidem hoje com as do mundo. Se eu precisasse resumir a evoluçáo do mundo em um telegrama, a mensagem seria a seguinte: o século XX foi marcado pelo desenvolvimento do princípio da autodeterminaçáo dos povos, pelo nascimento de mais de uma centena de Estados, pela tendência em se reconhecer os direitos do homem e as liberdades fundamentais; devido ao aparecimento e desenvolvimento de um novo sistema políticoeconômico que prometia a igualdade e a justiça a todos e tornou-se fonte de numerosos males e de destruiçóes, antes de desaparecer na falência e no desmoronamento; um século do qual o futuro reterá a imensa parte que assumiu do progresso da ciência e da tecnologia, ao tomar posse da natureza e dominá-la, transpondo os limites dos mais recuados espaços. O homem tornou-se mais poderoso que nunca, e é capaz hoje de destruir a si próprio, e mesmo de destruir todo o planeta. Entretanto, um século em que somente nos anos de 1910 e 1927 nenhuma guerra se desencadeou em qualquer ponto do globo. Um século cujos dois últimos decênios suscitaram novas esperanças de futuro melhor para a humanidade. Eu poderia evocar dois acontecimentos recentes de grande importância: Maastricht e Alma Ata, símbolos não apenas de momentos decisivos nas dimensóes euro-asiáticas, mas também de desenvolvimentos jurídicos marcantes na virada deste século.

O direito dos povos de disporem de si próprios, pouco a pouco, abriu seu caminho até hoje. Esse caminho passou do sistema da missão sagrada para o regime dos mandatos e da tutela. Algumas entidades se beneficiaram com o princípio da autodeterminação, na véspera da I Guerra Mundial, mas o sistema colonial só sofreu o choque decisivo após a Segunda Guerra. Por isso, assistimos a um aumento prodigioso do número de Estados: havia 14 Estados no Congresso de Madri em 1880; 44 Estados participaram da segunda Conferência de Haia; 47 Estados estavam representados em 1920 na primeira sessão da Assembléia da Sociedade das Naçóes; atualmente, há 175 Estados membros da ONU. Eis um resultado muito importante: 70 territórios colocados, em 1946, sob a tutela das Naçóes Unidas ou beneficiando-se da autonomia interna puderam, a partir de 1960 , exercer seu direito de autodeterminaçáo. Um dos fenômenos dentre os mais interessantes nessa longa evolução é o nascimento da Namíbia, anteriormente Sudoeste Africano. A Namíbia é, indiretamente, filha da Corte Internacional de Justiça, que 
pronunciou, em 1971, a seu respeito, um parecer consultivo bem conhecido sobre a ilegalidade da ocupaçáo pela África do Sul; em 21 de março de 1990, o primeiro presidente da Namíbia, San Nujoma, prestava juramento em presença do Secretário Geral das Naçóes Unidas, após consulta colocada sob o controle das Nações Unidas, que permitiu a eleiçăo de uma Assembléia Constituinte, da qual participam 72 delegados representando sete partidos políticos. Viu-se, assim, o exemplo de uma notável liçáo de democracia e as Naçōes Unidas prometeram dar ao povo da Namíbia todo seu apoio, o que denominou-se 0 desafio da construfá̃o de uma nafão. Não se pode, entretanto, ignorar as dúvidas levantadas no momento de saber se o princípio da autodeterminaçáo produziria resultados positivos. Como foi dito há quase meio século, "Multiplied sopereign States and witbin twenty years nationalism depoured all its children. All the new nations bave been conquered and enslaped " (2). Năo é verdade, mas, como disse o grande jurista Boutros Boutros-Ghali, falando da África, esta "sofre do micronacionalismo: umas cinqüenta soberanias de Estado (ou seja, o duplo das do continente americano) partilham ocontinente africano. Esses Estados, em sua maioria, não têm nem a diversidade econômica, nem a dimensáo do desenvolvimento" (3).

A esse respeito, deixando nossa reflexáo avançar nesse terreno, posso apenas citar as palavras que me foram ditas por Jawaharlal Nehru: "Esses países", disse-me ele, "alcançam a inde-

\section{MANFRED LACHS}

Creio que a publicação de "O Direito Internacional nos umbrais do século XXI", do juiz Manfred Lachs, na revista Estudos Apanfados, representa uma admirável avaliaçáo do desenvolvimento da regulamentaçāo jurídica das relaçóes internacionais neste século de transformaçōes extraordinárias, bem como dos principais problemas que tal mecanismo deverá enfrentar na virada do século.

Năo lembro ter visto nada semelhante em publicaçóes brasileiras. Entre nós, é comum minimizar-se as questóes jurídicas internacionais e superdimensionar os aspectos económicos e políticos.

Manfred Lachs figura entre os maiores mestres do Direito Internacional deste século. Ele ganhou projeçăo como poucos juízes que passaram pela Corte Internacional de Justiça, de Haia, da qual foi um dos presidentes que marcou época. Polonês e, por isto, oriundo de um dos campos claramente demarcados pela guerra fria, năo se deixou levar por este confronto avassalador e conseguiu manter-se acima dele, respeitado por ambos os contendores como defensor incansável de valores humanistas e soluçōes benéficas a todas as naçóes. Esteve envolvido nos últimos $\mathbf{3 0}$ anos com os mais espinhosos processos de negociaçăo na ONU em torno dos principais acordos firmados neste período. 
pendência, mas não chegam à liberdaden. Eis aí um sério inconveniente no conjunto do processo de descolonizaçáo. Muitos desses novos Estados independentes foram submetidos a novas formas de dependência, a novas ditaduras. A aurora da liberdade nunca lhes surgiu. Esta $t$ a herança deixada pelo século XX em numerosas partes do mundo, isto é, uma desigualdade dos Estados face ao desenvolvimento. Por outro lado, subsistem problemas aqui e ali que ainda esperam uma soluçáo. Podem ser citados os problemas colocados pelas minorias e pelas fronteiras. Todos esses problemas pedem soluçáo. Se posso evocar a Uniáo Soviética, a antiga União Soviética, direi que problemas idênticos tendem a colocarse nos vastos espaços que a constituíam.

Por estranha coincidência, a tecnologia moderna pode fazer da ilha minúscula e pobre que é o Reino de Tonga um parceiro da comunidade internacional dos satélites de telecomunicaçóes. Com efeito, foi divulgado recentemente que essa ilha de $\mathbf{2 2 . 0 0 0}$ habitantes e de superfície de $699 \mathrm{~km}^{2}$, situada ao norte da Nova Zelândia, celebrara há pouco um contrato de locaçáo com uma sociedade americana, conferindo-lhe o direito de colocar satélites em órbita geoestacionária. Em troca, Tonga receberá uma parte dos lucros resultantes dessa operaçáo.

Vivemos hoje em um mundo de Estados-naçōes. Assistimos à criação de numerosos Estados que não são viáveis e que têm dificuldades para assegurar sua subsisténcia. Por outro lado, há uma tendência para a integraçáo dos Estados, táo bem ilustrada pela criaçáo da Comunidade Européia, que tem a ambição de incluir não apenas a Europa Ocidental, mas o conjunto do continente europeu, tornando-se, assim, uma entidade multinacional de tipo e dimensóes novos.

Dessa forma, o século XXI tem todas as possibilidades de assistir ao começo de um capítulo inteiramente novo da história das naçōes, que resultará no reagrupamento de pequenos Estados em conjuntos mais amplos e este será um elemento essencial à sua sobrevivência. Pode-se desejar que esses Estados se beneficiem dos progressos realizados alhures nos domínios da liberdade, da democracia e de uma liberdade real.

Os direitos do homem penetraram no âmago das relaçóes internacionais. Os dois pactos internacionais referentes aos direitos políticos, econômicos e sociais, assim como inúmeros acordos regionais eliminaram as primeiras dificuldades a esse respeito. Assim, o Direito Internacional, em larga medida, transpôs a barreira do domínio reservado dos Estados.

A criação de uma Corte Européia dos Direitos do Homem e a instituição de órgáo similar na América Latina representam etapas 
importantes dessa progressão. Hoje, com a extinçáo do totalitarismo e a adesáo dos países do Leste ao Conselho da Europa, os direitos do homem sobre o conjunto do continente europeu podem ser completamente garantidos.

Entretanto, o reino dos direitos humanos ainda náo se estendeu a todo o planeta. Persistem numerosas regiốes no mundo onde esses direitos sấo desconhecidos, onde a discriminaçăo prospera. Nessas regiōes, o balanço do século XX revela progressos. Esses progressos, porém, são insuficientes; novas etapas deverão ser transpostas a uma velocidade maior no curso do século vindouro.

Todavia, parece que estamos prestes a ver atribuído ao indivíduo um status sequer imaginado no início deste século, isto é, o status de um sujeito limitado pelo Direito Internacional. Tentativas nesse sentido já foram feitas pelo Tratado de Versalhes, com o estabelecimento de Tribunais arbitrais mistos ou com a conclusáo do Tratado entre a Alemanha e a Polónia sobre a Alta Silésia em 1922. A Corte Permanente de Justiça Internacional, no caso do Serviço Postal em Dantzig, admitiu que indivíduos podem adquirir diretamente direitos em virtude de tratados. Os Tratados de Paz de Paris de 1946, nesse sentido, representaram retrocesso. A Carta do Tribunal Internacional de Nuremberg $e$ a do Tribunal que se instalou em Tóquio reconheceram o princípio de responsabilidade direta dos indivíduos em Direito Internacional. Infelizmen-
Esta experiência fascinante se reflete no artigo em pauta, texto de sua última conferência no Collège de France, em 10 de janeiro de 1992, exatamente um ano antes de seu falecimento.

Situado no fogo cruzado das grandes potências em meio a batalhas jurídicas de agudas implicaçóes estratégicas, nunca perdeu, no entanto, a sensibilidade dos problemas sociais de envergadura global, bem como dos efeitos contraditórios do acelerado avanço da ciência e da tecnologia em nosso tempo - bem ao contrário de outros eminentes juristas do chamado Primeiro Mundo.

Partindo do reconhecimento de que os países pobres nāo estáo em posiçāo de oferecer condiçōes de reciprocidade, como exigem os países ricos, ele menciona a tarefa, da mais alta significação: "construir um sistema de cooperação em um mundo que se modifica rapidamente". Para tanto, a seu ver, "o direito pode desempenhar papel muito importante, se a vontade política estiver madura; o tempo está maduro".

As confrontaçóes de força devem ser substituídas pelas lutas de procedimento. É a grande liçáo de Lachs que merece ser melhor conhecida no Brasil.

* José Monserrat Filho, jornalista, é editor da revista Ciencia Hoje. 
te, esses exemplos não foram seguidos ulteriormente, embora as ocasióes para fazê-lo não tenham faltado. Os refugiados e os apátridas deveriam desaparecer enquanto categorias à parte. $O$ terrorismo, que representa uma chaga de nosso século, está felizmente em declínio e deveria também desaparecer.

Devo lembrar a contribuição trazida pelas Naçóes Unidas ao controle de eleiçóes livres em inúmeros países; a grande obra de codificação de tão numerosos capítulos do Direito Internacional que concerne às relações diplomáticas e consulares, ao direito dos tratados, à sucessão de Estado em dois de seus aspectos, ao desenvolvimento do Direito do Mar - um dos importantes novos capítulos do Direito Internacional -, aos direitos e deveres dos Estados; ao arbitramento. Mas a ordem do dia da codificação permanece aberta. Novos imperativos resultam do desenvolvimento da ciência e da tecnologia, pela evoluçáo das relaçôes entre o homem e a natureza.

Desde a Revolução Industrial, mudanças fundamentais se produziram nas relaçóes entre o homem e a natureza, constatando-se que o homem tem obtido resultados surpreendentes. A ciência e a tecnologia irromperam em nossa vida quotidiana. Desde o início deste século, a rapidez das comunicaçóes em seu conjunto conheceu uma aceleração da ordem do milhão, como mostrou François Jacob, enquanto a capacidade do homem de deslocar-se de um lugar para outro aumentou na ordem do milhar. Sabemos da existência de aparelhos fabricados pelo homem que lhe permitiram realizar seu primeiro vôo no céu, depois no espaço e, agora, entre as estrelas. Novos problemas surgiram. Tenho necessidade de repetir que vivemos em uma época na qual a ficçáo científica corresponde à ciência dos próprios fatos? Se podemos fazer a volta ao mundo em menos de cinqüienta horas, um bilháo de passageiros utilizam os transportes aéreos e perto de $\mathbf{1 7 . 0 0 0}$ navios de tonelagem igual a 413.257 milhốes de toneladas acham-se sobre os mares e os oceanos, nas regióes do Ártico e do Antártico, e se cruzam acima do leito do mar do qual podemos extrair, para explorá-los, novos recursos, se isso se mostrar necessário. Como poderíamos fazê-lo sem regulamentaçăo jurídica? Criamos o conceito de plataforma continental, produto da tecnologia moderna. Hoje, estamos utilizando novas fontes de energia tais como a solar, a nuclear que abriram um novo capítulo do direito. $O$ direito de propriedade desenvolveu-se em novas direçóes, como o direito das patentes, das marcas, os direitos de autor ou o desenho industrial e a televisão. As telecomunicações realizam milagres. Dos 175 Estados, pelo menos 100 produzem programas transmitidos para além de numerosas fronteiras. Esses Estados operam na base da atribuiçáo de comprimento de ondas e de frequiências. A liberdade do ar é respeitada na 
prática, embora os Estados continuem a afirmar sua soberania sobre o espaço aéreo que se acha acima de seu território.

Novos problemas surgiram no que diz respeito às relaçóes entre 0 homem e o meio ambiente. Os fusíveis do planeta saltam uns após os outros. Como tive ocasiāo de dizer, durante um debate público sobre o meio ambiente, há alguns anos, após o desastre do Amoco Cadiz, em um mundo onde camadas de petróleo se deslocam das costas da França até as costas mais meridionais da América Latina, quando a poeira das minas de carvão da Europa Central se espalha sobre os fiordes da Noruega, quem sáo os vizinhos? Somos todos vizinhos uns dos outros e nos tornamos conseqüentemente titulares dos direitos e dos deveres daí decorrentes. Um novo conceito de responsabilidade - com certeza - faz, de hoje em diante, parte do dicionário do Direito Internacional. $O$ ponto de vista segundo o qual o desenvolvimento da ciência, o meio ambiente e o direito são atores rivais é, com razão, inteiramente contestado. Todos esses elementos devem funcionar de acordo e com rapidez: de tal modo a permitir afrontar as tarefas difíceis. O Programa das Naçóes Unidas para o Meio Ambiente deve ser reforçado - é preciso criar um Conselho para o Meio Ambiente como órgão principal (substituindo o Conselho de Tutela).

Eu poderia prosseguir estabelecendo a lista desses inúmeros milagres que devem encontrar e encontram seu prolongamento em regras de direito correspondentes. A tecnologia e a ciência criaram nova forma de interdependência nunca vista antes, que leva os Estados concernidos a cooperarem entre si em seu interesse mútuo.

Em numerosos outros domínios, o Direito Internacional progrediu. Foi criado um grande número de organizaçóes internacionais. A Organizaçáo Internacional do Trabalho pode orgulhar-se de ter presidido à adoção de 171 convençóes e de 176 recomendações. A Organização da Aviaçáo Civil Internacional procedeu, por quatro vezes, à revisão de suas regras constitutivas; unificou o direito privado do transporte aéreo. A Organizaçáo Mundial da Saúde defendeu inúmeros princípios importantes, em particular os que dizem respeito à proteção da saúde humana. A Organização Marítima Internacional é, ela própria, o reflexo da cooperaçáo internacional. Apenas na Europa, se considerarmos o Conselho da Europa, 140 convenções foram concluídas. Assim, entramos no século XXI dispondo de um balanço considerável e estamos muito orgulhosos dos resultados obtidos ao longo dos últimos anos. Noções como o patrimônio comum da humanidade, os direitos e obrigaçóes dos Estados ergo omnes, o conceito renovado de vizinhança, o jus cogens, todas essas noçōes tomaram a forma diversificada de um labirinto, de que os Estados podem, com justa razáo, orgulhar-se. Exigências 
que repousam sobre a existência de regras recíprocas podem conferir a certas práticas, mesmo se elas não tiverem o caráter positivo do direito consuetudinário, a qualidade de um aguilhão.

A Comissão do Direito Internacional transmite ao século XXI herança importante, embora os assuntos inscritos em seu programa de trabalho não sejam todos os melhores ou náo estejam preparados para um empreendimento de codificaçáo e náo cheguem a resultar todos em tratados de codificaçăo. Mas um corpo importante de regras jurídicas se desenvolveu, do qual numerosos capítulos têm um caráter declaratório do direito existente. Alguns Estados puderam evitar ligar-se, até o momento presente, mas considerando as mudanças ocorridas, podem ter uma visão mais próxima da realidade dos fatos.

Fenômeno interessante, um dos traços característicos deste último quarto de século, t́ o desenvolvimento dos instrumentos internacionais resultantes da atividade de organizaçóes internacionais. Dizendo isso, penso em suas decisóes. "The danger today is that international law may be submerged under the rival empires of paper emanating from assemblies of Government delegations" (4), há hoje o perigo de que o Direito Internacional seja submergido pelos impérios rivais que são as massas de papel produzidas pelas assembléias de delegaçóes governamentais. Entretanto, à medida em que é preciso permanecer dentro de limites razoáveis, essas resoluçōes representam antes uma fonte de ilusōes. Pois, se os Estados têm consciência de não terem elas força obrigatória e de ser necessário, para uma regra de direito ter caráter constrangedor, que deva transpor de antemão o limiar do reino do direito, como afirmei em meus escritos, o perigo apresentado por essas resoluçóes năo é significativo. Mas a vantagem dessa prática é considerável visto que ela fornece aos governos um campo de açóes e estes podem decidir atribuir um caráter de obrigação a uma dentre elas.

Do mesmo modo, é preciso observar, a esse respeito, o fenômeno interessante representado pelo aparecimento do que foi estabelecido chamar códigos de conduta, adotados por organizaçōes como a OCDE, a Organizaçăo das Naçóes Unidas ou CNUCED.

Assim, novas técnicas de criação do direito apareceram e representam ferramentas importantes na época atual. Isso é igualmente um dos valores que este século vai transmitir ao que virá.

O crescimento do corpus jurídico e seu desenvolvimento modificaram de forma considerável o conceito de soberania do Estado, e este é fenômeno bem conhecido. Hoje, noçáo de uma soberania ilimitada do Estado está completamente prescrita. Ser-me-iam necessárias inúmeras 
exposiçóes para apresentar-lhes os setores onde a soberania do Estado viu-se limitada, a exemplo de quando me referi ao domínio dos direitos do homem ou das telecomunicaçóes.

Se, no interior de suas fronteiras territoriais, os Estados, no exercício de seus poderes, náo podem transpor certos limites, é preciso também considerar o fato de os Estados terem igualmente o direito de regulamentar as atividades que se desenvolvem fora de sua fronteira. Desse modo, o Estado pode exercer seu controle de modo particular sobre atividades econômicas e tecnologia. Há uma tendência histórica evidenciando que a liberdade de ação dos Estados deixou progressivamente de ser considerada como sem limites.

O Direito Internacional de nosso século também teve progressos consideráveis, dos quais podemos nos orgulhar, apesar das dificuldades políticas e dos conflitos que se apresentaram. Temos consciência das mudanças prodigiosas que se produziram ao longo dos últimos anos e podemos prever para o Direito Internacional desenvolvimento particularmente brilhante. Ele não mais virá do acaso representado pela inspiraçáo do jurista ou do homem de Estado, que surge no momento oportuno em que seu conteúdo pode ser aceito. Ele não mais será o produto de especulaçóes artificiais. Estará simplesmente na realidade a formulaçáo do que deve acontecer. Nessa pluralidade, que pode criar a harmonia indispensável ao desenvolvimento de cada Estado e de todos os Estados, reside o futuro do Direito Internacional, através do conjunto das resoluçốes tendo em vista o interesse dos que se acham envolvidos. Um dos avanços mais convincentes a esse respeito é o feito pela Comunidade Européia.

O Direito Comunitário, precedendo doravante o Direito Nacional, é também o produto dessa faculdade de invençáo que têm os tribunais. Pode-se dizer que um dos capítulos mais fascinantes é aquele que, estamos lembrados, conduziu, pela adoção de $\mathbf{2 7 9}$ diretivas, qualificadas de 300 por ser mais breve, à adoçáo do Ato Único Europeu, em 1986. Pensou-se na época que esse instrumento não ameaçava a soberania nacional. Estamos diante de um conjunto de fórmulas coerentes que leva em consideraçáo os interesses de todas as partes interessadas. Trata-se de fenômeno "indissociável de um dever de não agressáo e de boa vizinhança", como foi dito recentemente: "... sem o que, não é uma Europa sem fronteira, mas um continente com cem fronteiras" (5).

Um capítulo especial do desenvolvimento do direito é certamente constituído pela jurisprudência dos tribunais e esse fenômeno atingiu proporções sem precedentes. Sir Henry Maine, em seu curso pronunciado em 1887, faz referência a três processos apenas. Oppenheim, na 
primeira edição de seu Droit International, em 1905, menciona 231 processos; um manual publicado em 1970 menciona 2.000 casos. Esses números compreendem as decisóes da Corte Internacional de Justiça e as de outros tribunais, especialmente as decisóes pronunciadas por tribunais de arbitramento.

Por isso, os decretos são instrumentos indispensáveis ao desenvolvimento do Direito Internacional. São de extrema importância para o desenvolvimento do Direito Comunitário. Trata-se de fenômeno bem conhecido, levado em consideração por todas os projetos de desenvolvimento e de codificaçáo do Direito Internacional. Como disse precisamente Charles de Visscher: "A codificação, mesmo no sentido mais estrito, implicava sempre certo elemento legislativo, visto que visava realizar certa uniformidade e reduzir ao mínimo as diferenças existentes entre as diversas escolas".

É preciso igualmente lembrar que a codificação sempre permaneceu entre as mãos do legislador. Entretanto, em Direito Internacional, os primeiros projetos de codificação eram obra de indivíduos, os grandes codificadores dos séculos XVIII e XIX. Sua orientação, se considerados na perspectiva de hoje, teriam um caráter antiquado, vieux jeu, ou um caráter utópico. As funçōes preenchidas por esses projetos eram consolidação, harmonização, disciplina. Tal era o clima positivo do século XIX. A Europa deu nascimento aos codificadores. A intenção desses indivíduos era formular de modo claro as idéias da época, daquilo que se chamava entáo o mundo civilizado. E vale a pena lembrar que essa obra de codificação era freqüentemente consultada pelos diplomatas e por todos os que eram chamados a dar sua opiniáo sobre o Direito Internacional.

Em 1873, nova etapa foi evidentemente transposta com a criação do Instituto de Direito Internacional que, durante os cinqüenta primeiros anos de sua existência, graças à presença, entre seus membros, de professores de direito de real valor, contribuiu de maneira notória, tanto para o desenvolvimento progressivo, como para a codificaçáo do Direito Internacional. Entretanto, oitenta anos mais tarde, um de seus membros, Max Huber, que exercia grande influência sobre seus colegas, formulou comentário muito pertinente sobre os limites da contribuiçăo da comunidade professoral à codificaçáo do Direito Internacional. Declarou ele: "Provavelmente, o Instituto é uma instituiçáo científica que deve ter a coragem de dizer tudo o que ela pensa e de exprimir o direito, elevando-o, mas deve também levar em consideraçáo as realidades políticas e as possibilidades. Não se deve negligenciar as condições nas quais as idéias do Instituto podem passar à prática". (6). 
Tanto é evidente hoje como no passado, a codificação e a criação do direito acham-se a cargo dos legisladores. Os Estados, no século XX, embarcaram na grande aventura da codificaçáo. Em diversas ocasióes, julgamentos foram formulados a respeito da politizaçáo dos membros desses órgãos. Essa censura de politizaçáo foi igualmente formulada a propósito da Corte Internacional de Justiça. Há aí um vestígio da guerra fria, de que seria necessário ver-se livre táo depressa quanto possível. Entre os membros desses órgáos encontram-se pessoas de qualidades excepcionais, mas adeptas de diferentes filosofias jurídicas. Embora representando diferentes escolas de pensamento, os membros da Comissão do Direito Internacional concordam com a opiniáo de um deles de que se torna cada vez mais difícil sustentar ser impossível para os Estados encontrarem um terreno de consenso na base de livre consentimento.

Outro capítulo que permanece de importância fundamental é o papel da força nas relaçóes entre Estados. Após inúmeros esforços nesse sentido, o Direito Internacional contemporâneo conseguiu colocar fora da lei o emprego da força. Infelizmente, fomos testemunhas de inúmeros conflitos que se produziram ao longo dos anos entre velhos Estados e entre Estados novos. Esses conflitos foram a conseqüência da guerra fria e da descolonizaçáo. Houve, às vezes, guerras desencadeadas por Estados interpostos. Outras vezes, inimizades artificiais foram criadas. Raymond Aron escrevia, em 1962, que a Terceira Guerra Mundial se desencadearia por nada. Mas salientava: "... a aliança não escrita russoamericana contra a guerra não exclui a hostilidade fundamental entre esses dois parceiros" (Arts, 16 maio 1962).

Não penso que essa hostilidade fosse fundamental - ela era artificial, o resultado de um confronto da guerra fria.

Nosso século começou com uma tentativa de grande envergadura para estabelecer normas de conduta em caso de conflito armado. As duas conferências de Haia, seguidas por outras reunióes internacionais, construíram um edifício monumental destinado a servir de ponto de referência para as geraçóes vindouras. Infelizmente, as duas guerras que se seguiram destruíram a maior parte das normas adotadas. As guerras foram ilustraçóes clássicas da náo aplicação do Direito Internacional em caso de conflito armado. Entretanto, tornou-se claro, por outro lado, que não há lugar disponível em nossa época para qualquer empresa que tente fazer reviver os esquemas do passado. Nem os tratados de Utrecht, nem os congressos de Viena e de Versalhes, nem o acordo europeu, nem a divisáo do mundo em esferas de influência poderiam hoje produzir as condiçóes de paz duradoura. Pode-se relembrar sorrindo os dias em que Alberoni, representando a rainha da Espanha, podia dizer no Congresso 
de Utrecht: "Eles cortam e aparam os Estados e os reinos, como se fossem queijos holandeses." Esses problemas apareceram com a guerra fria.

Por outro lado, pode-se dizer que as relaçóes internacionais foram dominadas pelas alianças européias, muito particularmente no início deste século. Foi assim com a tríplice aliança entre a Inglaterra, a França, a Rússia, de um lado, e a Alemanha, a Áustria, a Hungria e a Itália, do outro. Nossos antepassados confrontaram-se com um mundo onde se achava uma obra feita à mão, da qual se disse ser apresentada sob a forma de "uma rede de segredos, de obrigaçōes contraditórias e por vezes ininteligiveis, cujo valor ninguém podia prever, nem mesmo interpretá-las, se chegassem a ser aplicadas." Network of secrecy, conflicting and almost unintelligible obligations of which no-one could foresee the palue, or epen the interpretation if they come into operation."

Foi então que as idéias de geografia política conduziram à geopolítica e esta última produziu deploráveis efeitos no domínio das relaçóes internacionais. Devem ser lembradas as obras de Friederik Ratzel e de Karl Haushofer (8).

A geopolítica invadiu o espírito dos filósofos, dos homens políticos, dos juristas e levou-os a acharem as vias e meios que explicam seu impacto sobre os Estados e sobre as relaçóes que eles mantêm uns com os outros. Suas implicaçóes estiveram na origem de efeitos contrários que se refletiram primeiramente na noçáo do que se convencionou chamar o equilíbrio das forças. $O$ equiltbrio era destinado a servir de corretivo à dominaçáo sem limites de um único Estado. Alguns pretenderam que se tratava do primeiro indício de uma ordem internacional que permitisse conciliar os interesses muito freqüentemente opostos dos Estados. Eis por que um importante homem político afirmou: "The classical solution of the problems of international order in peace... the firmest bond of alliances is mutual interest. Men easily unite against bim when they bave all reason to fear or to bate, by whom they have been greatly injured or by whom they suspect that no opportunity will be of renewing attack. A soluçáo clássica dos problemas de uma ordem internacional em situaçáo de paz,... o laço mais firme das alianças é o interesse mútuo. Os homens se unem facilmente contra ele quando têm razóes para temer ou odiar, pelas quais sofreram graves ferimentos ou pelas quais supōem que não haverá oportunidade de renovar o ataque" (9).

Afirmou-se também que a noçáo de equilíbrio apresentava similitudes com um lustre. Pretendeu-se que um país, que pratica uma política de equilíbrio, "náo tem amigos perpétuos, não tem inimigos naturais, mas tem apenas interesses eternos". Com mais flexibilidade, pode-se 
lembrar que um dos encantos da política is that it offers an opportunity to grow wary of one's friends (10). Entretanto, a história mostrou muito claramente que, em um mundo feito de equilíbrio e de conflitos, os confrontos eram inevitáveis. É o que obriga a mudar de posição na abordagem das relaçốes internacionais. Pois era preciso tornar inteiramente claro o fato "de que um mundo banal não é um mundo no qual não há conflito, mas é um mundo no qual conflitos e combates são conduzidos por vias políticas regulares, fora de qualquer recurso às armas, e passam do universo dos campos de batalha às câmaras do conselho $\mathrm{e}$ às salas de deliberaçōes dos tribunais."

Pretendeu-se mesmo que o equilíbrio teria por conseqüência permitir ao Direito Internacional produzir seus efeitos (11). " There is good reason to conclude that the balance of power would generally be compatible with and supportipe of international law " (12). Contudo, em qualquer posição que nos coloquemos para avaliar as funçōes do equilíbrio do poder $\mathrm{e} o$ balanço deste último na história, somos levados à conclusão de que foi um fracasso para a manutençáo da paz, e deve ser substituído por outras técnicas. Olhando a passagem do século XX para o XXI, devemos orientar nossa observação partindo do ponto de vista das realidades atuais e anteriores. Além disso, pode-se justamente pretender, como disse um grande especialista nesse domínio, que, no mundo complexo de hoje, o conceito de equilíbrio das forças "is no longer adequate because the nature of power has become too diverse ", "a força tomou um caráter demasiado diversificado" (13). Não se poderia mais encarar a possibilidade de um diretório internacional do tipo daquele que foi instituído pelas Conferências de Yalta e de Potsdam.

As liçōes que podem ser tiradas do século $\mathrm{XX}$ são, pois, as do desmoronamento da política de equilíbrio, que terminou por conduzir à dominaçáo do mundo por duas superpotências. Doravante, permanece a pergunta: o mundo poderia ser controlado por uma única superpotência?

Com efeito, a força assumiu um caráter multiforme e a existência de um só poder controlando o mundo é hoje inconcebível.

A primeira tentativa para criar um sistema internacional de segurança fracassou. A Sociedade das Naçóes não impediu o desencadeamento da Segunda Guerra Mundial, com todos os desastres que ela provocou. A conferência de San Francisco era esperança vã de ver as Naçóes Unidas funcionarem de modo efetivo, tanto quanto permanecia ignorado o princípio da cooperaçăo entre todas as grandes potências e entre todos os Estados. A partir daí, em todos os grandes problemas, desde o estabelecimento de um sistema de segurança coletiva até os 
numerosos problemas políticos e as fontes de controvérsia que figuravam na ordem do dia dos Estados membros, houve o impasse. A guerra fria instalou-se, com todas as suas conseqüências desastrosas.

A cada dia, novos armamentos surgem e novas armas sáo acrescentadas à panóplia dos Estados, até que esse acúmulo atinja o limiar de um poder de destruiçáo total. Felizmente, o último decênio deste século viu o início de uma mudança radical. As divisões do mundo desapareceram e a estratégia geopolítica que dominou nosso globo perdeu sua razáo de ser. Acontece o mesmo com o fator representado pela ideologia nas relaçōes internacionais. $O$ mundo que se desdobra diante de nossos olhos é um mundo multicor, mas feito doravante de uma única peça. Esse mundo deveria abrir suas portas a todos os homens de todas as naçóes, assegurando-lhes vida livre e decente. A divisão do mundo em dois blocos hostis, destinada a conservar um caráter permanente, náo é mais admissível e os homens políticos e os historiadores, que acreditavam que seria sempre assim, enganaram-se. Como foi dito com justa razão: "as cortinas de ferro artificiais de nossos dias não são tão inacessíveis quanto o eram as barreiras representadas pela distância, pela montanha, pelo mar e pelo deserto, nos tempos de nossos antepassados".

Embora o sonho de San Francisco não tenha se concretizado, não se pode negar que perspectivas estáo abertas no que diz respeito à possibilidade de aplicar as disposiçóes da Carta, de modo a fazer das Naçóes Unidas uma organização internacional muito eficaz. A eleição do professor Boutros Boutros-Ghali coloca, à frente das Naçóes Unidas, um grande jurista e homem de Estado que pode abrir um novo capítulo de sua história. O direito deve ser aplicado e desenvolvido; o parágrafo 4 do artigo $2^{\circ}$, da Carta permanece em vigor. A Organizaçăo deve, primeiramente, mudar sua maneira de funcionar. As disposições da Carta podem receber nova significaçáo; seus artigos podem ser interpretados de maneira a valorizar mais a cooperaçáo. Penso, de modo especial, no funcionamento do Conselho de Segurança. É da maior importância que o Comitê de Estado Maior torne-se realidade. Vários processos deveriam ser postos em movimento: primeiramente, seria útil organizar um grupo de crise, que funcionaria permanentemente e que vigiaria todos os riscos de conflito e todos os incidentes armados que se produzissem nas diversas partes do mundo. Dessa maneira, um sistema de radar seria instituído, de alguma forma preferível ao existente hoje, em que é preciso deter as hostilidades quando elas já começaram. Assim, a ONU poderia prevenir o desencadeamento de incidentes armados entre Estados. Eis uma proposição que fiz aos dois Secretários Gerais. Esse sistema de alerta, de caráter preventivo, seria extremamente válido, porque permitiria ao Conselho de Segurança tratar de problemas, nos quais a paz 
e a segurança estáo em jogo, antes mesmo que assumam caráter agudo ou que os combates se iniciem. Outra sugestão que me parece importante, objeto de discussóes durante certo tempo, é o estabelecimento de forças de manutençáo da paz da ONU em base permanente. Isso poderia ser feito no âmbito do Comitê de Estado Maior.

A crise do Golfo mostrou que era possível recorrer à ONU; quantas sançóes apresentando caráter repressor podiam ser aplicadas; quantas medidas militares podiam ser seguidas de resultados. O Conselho de Segurança autorizou os Estados a agirem: assim, os mecanismos da Carta mostraram sua eficácia através da cooperação das cinco grandes potências $O$ problema da legítima defesa torna-se de primeira importância. Embora o artigo 51 da Carta reconheça nesse direito o caráter de um direito inerente, esse direito permanece, entretanto, circunscrito, em virtude da formulação que a Carta lhe dá. Se é possível fazer uma projeção da situação presente no século XXI, pode-se imaginar que o Conselho de Segurança se tornará um instrumento de cooperaçăo internacional realmente efetivo, que salvaguardará os interesses dos Estados, grandes e pequenos.

Normas deveriam ser estabelecidas pela ONU no sentido de controlar, de fato, a exportaçáo e a importaçáo de armas, de modo que a Organização pudesse tomar medidas preventivas. $O$ direito que recai sobre o mandato das forças de manutenção da paz das Naçóes Unidas, como existe atualmente, deveria ser desenvolvido. No momento, uma operaçáo que implica o envio de militares, mas sem que sejam tomadas medidas de repressão, é posta em prática pela ONU para ajudar na manutençáo ou no restabelecimento da paz nas zonas de conflito. A fraqueza do atual sistema está em que, por sua própria natureza, "observadores militares, executando missóes de observaçăo, não são armados; militares que servem em forças de manutenção da paz dispóem de armas defensivas leves, cujo emprego só é autorizado em caso de legítima defesa".

Como salientou a própria ONU, essas forças de manutençáo da paz " preenchem o papel de uma terça parte imparcial e objetiva que tem por funçáo permitir e manter um cessar fogo e instituir uma zona de proteçáo entre os Estados em conflito. Essas forças tornaram-se instrumento importante que permite evitar a extensáo de um conflito local ou regional a zonas mais vastas."

Pode-se lembrar que as primeiras unidades, no âmbito da ONU, foram estabelecidas em 1947, mas não realizaram operaçóes de manutenção da paz. A partir de 1948 , as operaçóes se multiplicaram. Havia 14 operaçōes. Forças foram localizadas em Palestina, Coréia, Suez, 
Congo, Nova Guiné, India, Paquistão, Afeganistão, Líbano, Iêmen, Irá, Iraque, Namíbia, Angola, América Central e, finalmente, no contexto do conflito entre Iraque e Kuwait. As forças de manutençáo da paz, no sentido estrito do termo, nasceram em 1956, como forças de emergência no quadro do conflito entre Egito e Israel. Um caso especial foi o do Camboja: "Foram necessários dois anos, dois meses e uns vinte dias para se chegar à assinatura da paz no Camboja" - em 23 de outubro de 1991, em Paris - "a mais importante operação da história da ONU" (14).

As futuras forças de manutençáo da paz deveriam ser colocadas sob a autoridade do Comitê de Estado Maior, de acordo com os artigos 45 e 46 da Carta e, em particular, igualmente com o artigo 47. É essencial que o Capítulo VII da Carta seja efetivamente posto em prática. Mas é possível ir além. Poder-se-ia assim, por exemplo, colocar à disposiçáo do Conselho de Segurança, "a convite dele e em conformidade com um acordo especial ou com acordos especiais, as forças armadas, os meios de assistência e as facilidades..." (15), mas para dar todo seu sentido a essas disposiçōes, isso deveria ser feito em caráter permanente. Tais disposiçóes permitiriam abrir a porta à plena aplicaçáo dos parágrafos $2^{\circ} \mathrm{e}$ 30 do artigo 43. Alguém salientou recentemente que as operaçóes de manutenção da paz servem para estabelecer uma ponte entre os capítulos VI e VII da Carta (16). Ainda sobre isso, existem grandes possibilidades de se utilizar todas as forças de que os Estados dispóem colocandoas, no futuro, a serviço da ONU.

Há alguns anos, referi-me à possibilidade de redigir e de pôr em prática um estatuto para forças permanentes de manutençáo da paz da ONU. Atualmente, as forças são criadas na base de decisóes ad hoc, tomadas pelo Conselho de Segurança, no âmbito de situações particulares e para zonas territoriais bem-definidas. Seria preciso ter em vista, de fato, uma força da ONU de natureza permanente, que pudesse ser utilizada nas diversas regióes do mundo, segundo as necessidades, quando a situação o exigisse. Tenho todas as razóes para acreditar que tal reforma poderá ser posta em prática, em conjunto com a redução dos armamentos e a tendência geral para o desarmamento. Assim, a redução das armas nacionais poderia coincidir com a criaçáo de um instrumento internacional que seria dedicado à tarefa de manutenção da paz. Náo se trataria, falando com propriedade, de uma dissuasăo, mas de unidades que permitissem evitar confrontos similares aos que se desenvolvem sob nossos olhos na Iugoslávia. Isso traria uma resposta às necessidades urgentes da época atual e da própria ONU. Como Dag Hammerskjöld salientou um dia, haveria a possibilidade de atender às necessidades "de 
um mundo no qual a interdependência de todos os elementos torna-se cada vez mais estreita".

Essa evolução poderá transformar-se em um dos elementos importantes das relaçóes internacionais do século XXI. Não convém insistir sobre o caráter especial das armas nucleares, que mudaram a própria natureza dos confrontos militares. Não é apenas um problema moral. É simplesmente uma abordagem à Clausewitz: um novo confronto constituiria uma armadilha extremamente perigosa para todas as partes envolvidas. As armas nucleares deveriam ser geridas, como alguém propôs, por "uma Agência de Prevenção da Guerra Nuclear", criada por potências nucleares.

O segundo campo em que o direito pode desempenhar um papel importante, $\mathrm{e}$ isso imediatamente, é o do controle dos arsenais nucleares e da destruiçáo da maior parte deles. As mudanças radicais que se operaram ao longo dos últimos anos e dos últimos meses criaram sério perigo de proliferaçăo das armas nucleares. Em um mundo que evolui, como o nosso, é essencial evitar que a tecnologia mais moderna alimente um comércio ilícito ou sirva a outros fins semelhantes. Cabe ao universo do direito achar meios de controle adequados. A Agência Internacional da Energia Atômica realizou grande avanço quando estabeleceu controle sobre os reatores nucleares. Eis aí algo que deveria tornar-se universal. Com a solução progressiva dos litígios políticos, um controle estrito, de caráter universal, de todas as instalaçōes nucleares torna-se necessidade. Como os riscos são sérios, medidas devem ser tomadas sem demora. $\mathrm{O}$ desarmamento e o controle de todos os dispositivos e engenhos nucleares devem ser colocados em primeiro lugar na ordem do dia dos anos vindouros.

Um dos fatores essenciais do mundo de hoje é a economia. O problema das relaçóes entre o norte e o sul é da mais alta importância. Tentativas para pôr em prática novas regras com esse fim não foram coroadas de êxito: "a segurança coletiva para o desenvolvimento" não se converteu em fatos. O desenvolvimento é lento, as dívidas dos países do Terceiro Mundo e ex-comunistas geram enorme carga que eles, provavelmente, nunca poderão enfrentar. $A$ ordem econômica internacional existente é injusta, declarou a Assembléia Geral. "Não se trata seguramente de pobreza que seria remediada com transferência maciça de riquezas" . O professor F.-A. Hayek viu aí um "erro tradicional de raciocínio". Mas, como constava do relatório Brandt (1980): "Permitir que a pobreza continue, com a insegurança, os sofrimentos e a destruição que ela traz, vai contra os interesses de todos." O percurso é lento, mas o objetivo é claro. $O$ direito pode e deve oferecer as respostas adequadas. 
Somos sempre obrigados a enfrentar a radical oposiçáo que existe nas relaçóes entre os ricos e os pobres.

Os países pobres não estão em situação de oferecer condições de reciprocidade; seria ir além de seus meios. Por isso, pode-se empregar, a título de alternativa, o que foi chamado a graduafáto (17). Encontramse, em recentes disposiçōes do GATT (artigo VII), indicaçóes sobre as tendências das políticas que devem ser seguidas a esse respeito. Assim, um passo modesto, mas que tem, em última análise, caráter positivo para $o$ aproveitamento das novas relaçóes econômicas, poderia ser dado.

Entretanto, é preciso ter presente no espírito o fato de que convém fazer uma diferença entre um direito e uma expectativa. Por isso, existe uma tarefa a empreender, da mais alta importância, a de construir um sistema de cooperação em um mundo que muda rapidamente. $O$ direito pode desempenhar papel muito importante, se a vontade política estiver preparada. A ocasião é propícia.

A eqüidade assume caráter cada vez mais importante. Por isso, quando falamos de ordem internacional equitável, procuramos uma que seja não só formal, mas justa, uma ordem mais humana do que rigorosa. A ordem atual se traduz por um conjunto de relaçóes de força, no meio das quais existe uma disparidade surpreendente entre riqueza e pobreza. É essencial entrar no século XXI com a conviç̧áo de que o mundo precisa de soluçóes urgentes, pois tem registrado progressos gigantescos, mas deixa igualmente subsistir necessidades particularmente rigorosas.

Chegamos, provavelmente, a um capítulo em que, para utilizar as palavras de Georges Scelle, "os confrontos da força devem ser substituídos por lutas de processo". Volto à justiça internacional: os milhares de casos resolvidos pelo arbitramento e a atividade crescente da Corte Internacional de Justiça. Os Estados, em suas relaçóes mútuas, dispóem hoje de uma gama muito diversificada de meios de regulamentaçáo. Por outro lado, os Estados e as empresas acham-se engajados em um movimento importante de regulamentaçáo de divergências e de conflitos que podem existir entre eles. Esses tipos de regulamentação vão da negociação até o meio mais sofisticado: a regulamentação judiciária. É bastante justo dizer que não se tem recorrido muito freqüentemente à Corte Internacional de Justiça, filha deste século. Só foi possível armazenar uma colheita - em resumo - modesta. Mas, apesar de tudo, a Corte deu contribuição considerável à aplicação e ao desenvolvimento do direito. Ela conseguiu resolver grande número de litígios e pôs sua marca sobre o novo Direito do Mar. Felizmente, o fardo da guerra fria desapareceu progressivamente: os governos dos Estados da Europa, da Ásia e da África aceitaram a jurisdição da Corte com base no artigo 36 
do Estatuto. Hoje, a Corte é chamada a pronunciar-se sobre inúmeros litígios que têm sérias implicaçóes de ordem política. Ela trouxe uma contribuição importante, por seus pareceres consultivos, ao Direito das Organizaçóes Internacionais. De um desses pareceres consultivos, pôdese dizer com justa razão: "Esse parecer provavelmente náo atingiu de modo particular o homem da rua; mas ele constitui um marco na evoluçáo extraordinária do Direito Internacional que passou quase despercebida no ambiente sombrio e confuso da cena política contemporânea" (18).

Jules Basdevant tinha razão em dizer: "A justiça internacional disciplinou a ação das organizaçóes internacionais" - ela deu "uma contribuiçăo à paz". A Corte de Justiça das Comunidades Européias desempenhou papel muito importante no desenvolvimento do Direito Comunitário e mesmo em sua criação.

Em 1784, o marquês de Condorcet expressou sua visão: "Com toda probabilidade, podemos esperar um número menor de grandes mudanças, um número menor de grandes resoluçōes..."

As profecias são perigosas. Quanto a mim, não entrarei nesse terreno. Limitar-me-ei a tentar responder à pergunta final: qual é a situaçáo do Direito Internacional hoje? Pode-se falar de progresso em direito no alvorecer do século XXI? Não pode haver qualquer dúvida quanto a isso. A vida é possível graças a essa infinidade de regras que sáo diariamente aplicadas sobre a terra, no mar, no espaço atmosférico e no espaço extraatmosférico. A despeito dos caprichos do direito, seu progresso revelouse enfim irresistível e deve ser consignado. Vivemos em uma época de enorme desenvolvimento do Direito Internacional. Isso é um truísmo. Atualmente, é impossível viajar para qualquer lugar ou deslocar-se por muito tempo no espaço sem encontrar alguma norma de Direito Internacional. Nós a encontramos a cada encruzilhada. Pretender que o direito em geral e o Direito Internacional em particular esperem ainda seu Newton, Leibnitz ou Pasteur é levantar um falso problema. Tal afirmaçáo faz, muitas vezes, parte de um entusiasmo, como nas ciências naturais, por aquilo que é realmente ius ex factis oritur.

É preciso, evidentemente, levar em conta as realidades do poder e as pressóes que se prendem a isso; os interesses nacionais permanecem em competiçăo.

Em seu último livro, René-Dupuy salienta: "Visto que o Direito Internacional coloca à disposiçâo dos governos meios processuais... ele representa para a manutençáo da paz uma utilidade certa, na medida que os interessados estiverem dispostos a recorrer a ele." 
Entretanto, chegamos a um momento da história em que, considerada a complexidade das relaçóes internacionais e da interdependência, os interesses mútuos fizeram um progresso muito rápido: cada Estado tem, muito freqüentemente, interesse no respeito à regra de direito. Trata-se de preferência de uma escolha entre interesses em competiçóes (20). A dicotomia torna-se artificial. A vontade política é limitada por interesses mútuos dos Estados. A interdependência e a interpenetraçáo crescentes, nas quais sempre mais domínios os Estados se outorgam, criaram uma comunidade internacional jurídica ainda que imperfeita, frágil ou lacunar. Lembro-lhes as reflexōes de Michel Virally (21).

Como vemos, o direito é marcado ao mesmo tempo por uma necessidade de certeza e por uma necessidade de flexibilidade da regra jurídica. Os fenômenos internacionais indicam um progresso sem precedente do Direito Internacional.

Minhas conclusóes são breves e ouso pensar que sejam racionais: os juristas náo são os motores da história, mas podemos abrir a porta do século XXI convencidos de que o avanço galopante dos acontecimentos salienta a grande importância do Direito Internacional e exige seu desenvolvimento em todos os domínios da vida, caso contrário as relaçōes internacionais, mesmo quotidianas, correm o risco de tornar-se impossíveis.

\section{Notas}

1 Cf. W. H. McNeill, Conferência na Royal Historical Society, dez. 1981.

2 Cf. W. R. Inge, The anatomy of peace. Fortnigbtly, 1942.

3 B. Boutros-Ghali, $L$ OUA ducrant un quart de siecle. Contribution aux Melanges Rent-Jean Dupuy: bumanite at droit international. Paris, 1991, p. 57-58.

4 Sir Robert Jennings, The discipline of international law. Lord McNair, Memorial Lecture, International Law Association, 1976, p. 632.

5 M. Fouches, Fragments d'Europe du monde, 13 jul. 1991.

6 Annuaire de l'Institut de Droit International. Session d'Aix-en-Provence, 1954, v. II, p. 62.

7 J.A. Spender, Fifty years of Europe. A study of pre-war documents. New York, 1933, p. 35.

8 Cf. Friederik Ratzel, Politische geograpbie. Karl Haushofer foi um dos fundadores da geopolítica alemã, concebida enquanto instrumento da conquista da Europa por Hitler.

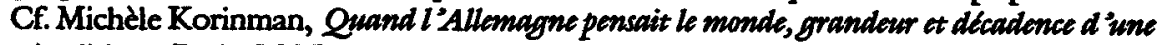
geopolitique. Paris, 1985. 
9 CF. sir Robert Walpole, Parliamentary history. v. 12, p. 168-169, par 5.

10 Cf. N.J. Spykeman, American strategy in zporld politics. New York, 1942, p. 103-104.

11 Cf. F. H. Hinsley, Poner and the pursuit of peace, 1963.

12 O. Schachter, International law in theory and practice, 78, R.CA.DI., 1982, p. 32.

13 Cf. Michel Howard, A new Commonwealth in need of British support. Times, 24 Apr. 1990.

14 Le Monde, 24 oct. 1991.

15 Cf. Artigo 43, parágrafo 1, da Carta.

16 Cf. Georges Paul Sloup, U.N. peace keeping in the age of ballistic missiles defence. American Institute of Aeronautics and Astronautics, 1991.

17 Cf. E. U. Pertersman, International Governmental Trade Organizations - GATT and UNCTAD. International Encyclopaedia of Comparative Law, 1981, p. 21.

18 Cf. Reparafaño dos danos sofridos a servifo da ONU, parecer consultivo, 11 abr. 1949 (A. Feller).

$19 L^{\prime}$ 'bumanite dans l'imaginaire des nations. Paris, 1991, p. 93.

20 Cf. L. Henkin, International Law, Politics Values and Functions, 216, R. CA.D.I.,1989, IV, p. 86-87.

21 Cf. Michel Virally, Panorama du Droit International, 183, R.CAD.I., V, p. 27 e seg.

\section{Resumo}

Ao longo do século XX, o número de Estados aumentou, assim como evoluíram a ciência e a tecnologia. Numerosos campos do Direito Internacional foram enriquecidos como mostra a intensa atividade das organizaçōes internacionais. As imensas mudanças deste século que termina explicam o sucesso da codificaçáo, assim como provocam uma modificação do conceito de soberania. O futuro, que pode ser concebido a partir do exemplo da guerra do Golfo e do papel desempenhado pela ONU, pode levar a uma força permanente da ONU e a um controle sobre as armas nucleares, mas também a um encaminhamento em direção à equïidade e à promoçăo da justiça internacional.

\section{Abstract}

During the 20th. century, the number of States has considerably increased and science as well as technology have been in constant evalution. The scope of international law was dramatically enlarged, as shown by the developping activity of international organisations. These stricking transformations, (which are actually reading an end with the collaps of an international society dominated until a recent past by the rivality between two superpowers) does explain the successes which have been known by the codification of 
international law. In the future, which can be forseen through the role played by the United Nations during the Gulf War, one could expect the outcome of a permanent force under the control of the United Nations, the limitation of nuclear weapons and the entrancement of international justice and equity.

Tradução de Durval Ártico e Maria Letícia G. Alcoforado. O original em francês - Le Droit International a laube du XXIe siecle - encontra-se à disposição do leitor no IEA para eventual consulta. 